\title{
Improved Mathematics Learning Outcomes with Powerpoint Media for Class 3 Elementary Student
}

\section{Sri Riningsih}

SDN 03 Tegalsari

sririningsih.pml@gmail.com

\section{Article History}

accepted 01/11/2020

approved 08/11/2020

published 15/11/2020

\section{Abstract}

The purpose of this study was to determine the increase in mathematics learning outcomes of subtraction material using powerpoint media for third grade students of SDN 03 Tegalsari.

Data collection methods used include documentation, test, and observation methods.

The research results obtained:

1. The average value of mathematics learning outcomes of class III students in cycle I was 66, in cycle II was 82 so that there was an increase in the average value from cycle I to cycle II.

2. The percentage of students 'learning completeness in cycle I was 54\%, in cycle II it was 92\% so that there was an increase in students' learning completeness from cycle I to cycle II.

Based on the information above, it can be concluded that: through powerpoint media it can improve mathematics learning outcomes in class III students of SDN 03 Tegalsari.

Keywords: Math, powerpoint, elementary school

\section{Abstrak}

Tujuan penelitian ini adalah untuk mengetahui peningkatan hasil belajar matematika materi pengurangan dengan media powerpoint pada peserta didik kelas III SDN 03 Tegalsari.

Metode pengumpulan data yang digunakan meliputi metode dokumentasi, tes, dan observasi. Hasil penelitian yang diperoleh:

1. Nilai rata-rata hasil belajar matematika peserta didik kelas III pada siklus I sebesar 66, pada siklus II sebesar 82 sehingga terdapat kenaikan nilai rata-rata dari siklus I ke siklus II.

2. Prosentase ketuntasan belajar peserta didik pada siklus I sebesar $54 \%$, pada siklus II sebesar $92 \%$ sehingga terdapat peningkatan ketuntasan belajar peserta didik dari siklus I ke siklus II.

Berdasarkan keterangan di atas, maka dapat disimpulkan bahwa : melalui media powerpoint dapat meningkatkan hasil belajar matematika pada peserta didik kelas III SDN 03 Tegalsari.

Kata kunci: Matematika, powerpoint, sekolah dasar

Social, Humanities, and Education Studies (SHEs): Conference Series https://jurnal.uns.ac.id/shes 


\section{PENDAHULUAN}

Peran pendidikan adalah meningkatkan kualitas sumber daya manusia, mewujudkan kesejahteraan umum, dan mencerdaskan kehidupan bangsa. Untuk itu, belajar sangat penting bagi diri sendiri maupun lingkungan. Pentingnya belajar untuk menumbuhkan sikap terbuka terhadap adanya perubahan dan tantangan globalisasi yang semakin modern dan menantang.

Dalam UU RI Nomor 20 Tahun 2003 tentang Sistem Pendidikan Nasional Pasal 1 menjelaskan pendidikan adalah usaha sadar dan terencana untuk mewujudkan suasana belajar dan proses pembelajaran agar peserta didik secara aktif mengembangkan potensi dirinya untuk memiliki kekuatan spiritual keagamaan, pengendalian diri, kepribadian, kecerdasan, akhlak mulia, serta keterampilan yang diperlukan dirinya, masyarakat, bangsa dan negara.

Guru perlu memahami karakteristik peserta didik dan materi yang akan disampaikan agar dapat menerapkan pembelajaran yang sesuai seperti sekarang terutama dalam pelajaran Matematika.

Pelajaran Matematika merupakan pelajaran berhitung yang dirasakan sulit oleh sebagian besar peserta didik. Kesulitan peserta didik pada pelajaran Matematika terletak pada materi pengurangan dua bilangan cacah. Hasil belajar peserta didik yang kurang pada materi pengurangan dua bilangan cacah di kelas III membuat guru perlu menggunakan model dan media pembelajaran yang menarik dan menyenangkan. Sehingga memudahkan peserta didik dalam memahami materi yang diajarkan.

Penggunaan media powerpoint dalam pembelajaran dapat menjadi alternatif dalam membantu guru untuk meningkatkan hasil belajar siswa pada materi pengurangan dua bilangan cacah dalam pembelajaran daring seperti sekarang ini.

Untuk melihat hasil dari implementasi penggunaan media powerpoint peneliti merumuskan membuat Penelitian Tindakan Kelas dengan judul "Peningkatan Hasil Belajar Matematika Materi Pengurangan Dua Bilangan Cacah dengan Media Powerpoint pada Peserta Didik Kelas III Semester 1 SDN 03 Tegalsari Tahun Pelajaran 2020/2021.

Berdasarkan latar belakang masalah peneliti dapat merumuskan masalah sebagai berikut: "Apakah penggunaan media powerpoint dapat meningkatkan hasil belajar Matematika materi pengurangan dua bilangan cacah pada peserta didik Kelas III Semester 1 SDN 03 Tegalsari?"

Tujuan dilakukannya penelitian ini antara lain secara umum PTK ini bertujuan untuk meningkatkan kualitas guru dan meningkatkan kualitas pembelajaran di SDN 03 Tegalsari sehingga memiliki nilai akademik yang baik. Secara khusus PTK ini bertujuan untuk mengetahui apakah penggunaan media powerpoint pada materi pengurangan dua bilangan cacah dapat meningkatkan hasil belajar peserta didik kelas III SDN 03 Tegalsari.

Skinner dalam Walgito (2009:166) memberikan definisi belajar "Learning is a process of progressive behavior adaptation". Belajar merupakan suatu proses adaptasi perilaku yang bersifat progresif. Ini berarti bahwa sebagai akibat dari belajar adanya sifat progresivitas, adanya tendensi kearah yang lebih sempurna atau lebih baik dari keadaan sebelumnya.

Piaget dalam Dimyati dan Mudjiono (2009:13) berpendapat pengetahuan dibentuk oleh individu. Sebab individu melakukan interaksi terus menerus dengan lingkungan. Lingkungan tersebut mengalami perubahan. Dengan adanya interaksi dengan lingkungan maka fungsi intelek semakin berkembang.

Berdasarkan pengertian belajar di atas dapat disimpulkan bahwa belajar adalah suatu proses untuk memperoleh perubahan perilaku sebagai hasil dari pengalaman seseorang.

Factor-faktor yang mempengaruhi belajar dapat digolongkan menjadi dua golongan saja, yaitu: (Slameto, 2010:54) 
a. Factor intern

Factor intern yaitu factor yang ada dalam diri individu yang sedang belajar. Dalam factor intern terdapat tiga factor penting yaitu: factor jasmaniah, factor psikologis, dan factor kelelahan. Factor jasmaniah meliputi factor kesehatan dan cacat tubuh. Factor psikologis sekurang-kurangnya ada tujuh factor yaitu : inteligensi, perhatian, minat, bakat, motif, kematangan, dan juga kesiapan.

b. Factor ekstern

Factor ekstern yaitu factor yang ada di luar individu. Factor ekstern dikelompokkan menjadi 3 faktor, yaitu: factor keluarga, factor sekolah, dan factor masyarakat.

Factor keluarga memberikan berbagai macam interaksi yang berpengaruh kepada peserta didik, berupa: cara orang tua mendidik, relasi antara anggota keluarga, suasana rumah tangga, dan keadaan ekonomi keluarga.

Factor sekolah yang mempengaruhi belajar mencakup metode mengajar, kurikulum, relasi guru dengan peserta didik, relasi peserta didik dengan peserta didik, disiplin sekolah, alat pelajaran, waktu sekolah, standar pelajaran, keadaan gedung, metode belajar, dan tugas rumah.

Sedangkan factor masyarakat meliputi kegiatan peserta didik dalam masyarakat, teman bergaul, dan bentuk kehidupan masyarakat.

Menurut Dimyati dan Mudjiono (2009:3) hasil belajar merupakan hasil dari suatu interaksi tindak belajar dan tindak mengajar. Pendapat tersebut menekankan bahwa hasil belajar berasal dari suatu interaksi. Interaksi adalah komunikasi antara guru dan peserta didik. Dari sisi guru, tindak mengajar diakhiri dengan proses evaluasi hasil belajar.

Menurut Suprijono (2009:5) hasil belajar adalah pola-pola perbuatan, nilai-nilai, pengertian-pengertian, sikap-sikap, apresiasi, dan ketrampilan. Ini berarti hasil belajar merupakan cerminan peserta didik pada saat melakukan proses pembelajaran.cerminan ini merupakan akibat dari terjadinya suatu proses interaksi antara guru dan peserta didik yang disebut dengan proses pembelajaran.

Berdasarkan pengertian hasil belajar di atas, dapat disimpulkan bahwa hasil belajar adalah hasil yang diperoleh seseorang setelah melakukan proses pembelajaran.

Menurut Criticos (1996) dalam Daryanto (2012:4) media merupakan salah satu komponen komunikasi, yaitu sebagai pembawa pesan dari komunikator menuju komunikan.

Menurut Ramiszowki dalam Wibawa (2001:12) media ialah pembawa pesan yang berasal dari suatu sumber pesan (yang dapat berupa orang atau benda) kepada penerima pesan.

Media pembelajaran merupakan alat atau sarana untuk berkomunikasi dengan peserta didik dalam proses pembelajaran yang digunakan untuk menyalurkan pesan sehingga dapat merangsang peserta didik untuk belajar.

Pemilihan media pembelajaran tidak semata-mata hanya karena menarik tetapi juga harus mempertimbangkan agar media yang digunakan dalam pembelajaran dapat membantu tercapainya tujuan pembelajaran yang diharapkan.

Menurut Fatkhan Amirul Huda (2018) media power point merupakan suatu software yang akan membantu dalam menyusun sebuah persentase yang efektif, profesional, dan juga mudah. Power point akan membantu sebuah gagasan menjadi lebih menarik dan jelas tujuannya jika dipersentasikan karena power point akan membantu dalam pembuatan slide, outline persentase, persentase elektronika, menampilkan slide yang dinamis, clip art yang menarik, yang semua itu mudah ditampilkan di layar monitor komputer.

Hasil penelitian yang relevan dengan penelitian yang dilakukan peneliti yaitu skripsi milik Deny Irawan (2013) yang berjudul "Keefektifan Media Slide Presentasi 
terhadap Minat dan Hasil Belajar Siswa pada Pembelajaran Matematika Materi Bangun Datar di Kelas III Sekolah Dasar Negeri 06 Tegalsari Kabupaten Pemalang". Hasil penelitian menunjukkan bahwa tingkat minat belajar pada pre test $46,1 \%$ atau sedang, pada post test $78,5 \%$ atau sangat tinggi. Nilai rata-rata prasiklus 42,7 , siklus I 53,52, siklus II 75. Ketuntasan belajar prasiklus 27,5 \%, siklus I 38,09 \%, siklus II 90, $47 \%$. Terjadi peningkatan hasil belajar setelah menggunakan media slide presentasi atau powerpoint. Dengan demikian dapat disimpulkan bahwa penggunaan media slide presentasi atau powerpoint dapat meningkatkan minat dan hasil belajar matematika materi bangun datar di kelas III SDN 06 Tegalsari.

\section{METODE}

Jenis penelitian yang dilakukan adalah berupa penelitian tindakan kelas. Subjek yang akan diteliti adalah peserta didik kelas III SDN 03 Tegalsari yang berjumlah 13 peserta didik terdiri dari 6 peserta didik laki-laki dan 7 peserta didik perempuan. Penelitian ini dilaksanakan di Kelas III SDN 03 Tegalsari yang beralamat di Dukuh Dampit, Desa Tegalsari Timur, Kecamatan Ampelgading, Kabupaten Pemalang.

Teknik pengumpulan data yang digunakan yaitu teknik dokumentasi, tes, dan pengamatan (observasi). Teknik dokumentasi digunakan untuk mengumpulkan data yang berkaitan dengan daftar peserta didik kelas III, jumlah peserta didik kelas III, baik laki-laki maupun perempuan, dan daftar nilai peserta didik kelas III. Tes dilakukan setiap akhir siklus untuk mengetahui hasil belajar peserta didik kelas III khususnya untuk peningkatan hasil belajar peserta didik dengan menggunakan media powerpoint. Data hasil belajar peserta didik ini didapat dari hasil evaluasi setiap akhir siklusnya. Pengamatan bertujuan untuk memperoleh data tentang proses berlangsungnya belajar mengajar yang meliputi aktivitas peserta didik, suasana atau situasi belajar peserta didik.

Data hasil belajar peserta didik diambil dari kemampuan peserta didik dalam memecahkan masalah. Analisis data hasil belajar dilakukan dengan cara menghitung rata-rata nilai dan ketuntasan belajar peserta didik secara klasikal.

\section{HASIL DAN PEMBAHASAN}

Dari hasil evaluasi pada kegiatan pembelajaran prasiklus dapat diketahui hasilnya sebagai berikut :

Dari 13 peserta didik yang mengikuti pembelajaran matematika dapat diketahui nilai tertinggi yang diraih peserta didik adalah 80 dan yang terendah adalah 50 , dengan rata-rata hasil ulangan harian adalah 62 . Prosentase ketuntasan peserta didik yang diperoleh yaitu sebanyak $31 \%$ peserta didik tuntas dan $69 \%$ peserta didik belum tuntas. Adapun data lengkap perolehan nilai peserta didik prasiklus dapat dilihat pada tabel berikut :

Tabel 1. Rekapitulasi Hasil Belajar Peserta Didik Prasiklus

\begin{tabular}{llll}
\hline Nomor & Nilai & Frekuensi & Prosentase \\
\hline 1 & 80 & 1 & $7,7 \%$ \\
2 & 70 & 3 & $23,1 \%$ \\
3 & 60 & 6 & $46,1 \%$ \\
4 & 50 & 3 & $23,1 \%$ \\
\hline Jumlah & & 13 & $100 \%$ \\
\hline
\end{tabular}



berikut :

Dari data dalam tabel 1 diatas, bila dibuat dalam bentuk diagram maka sebagai

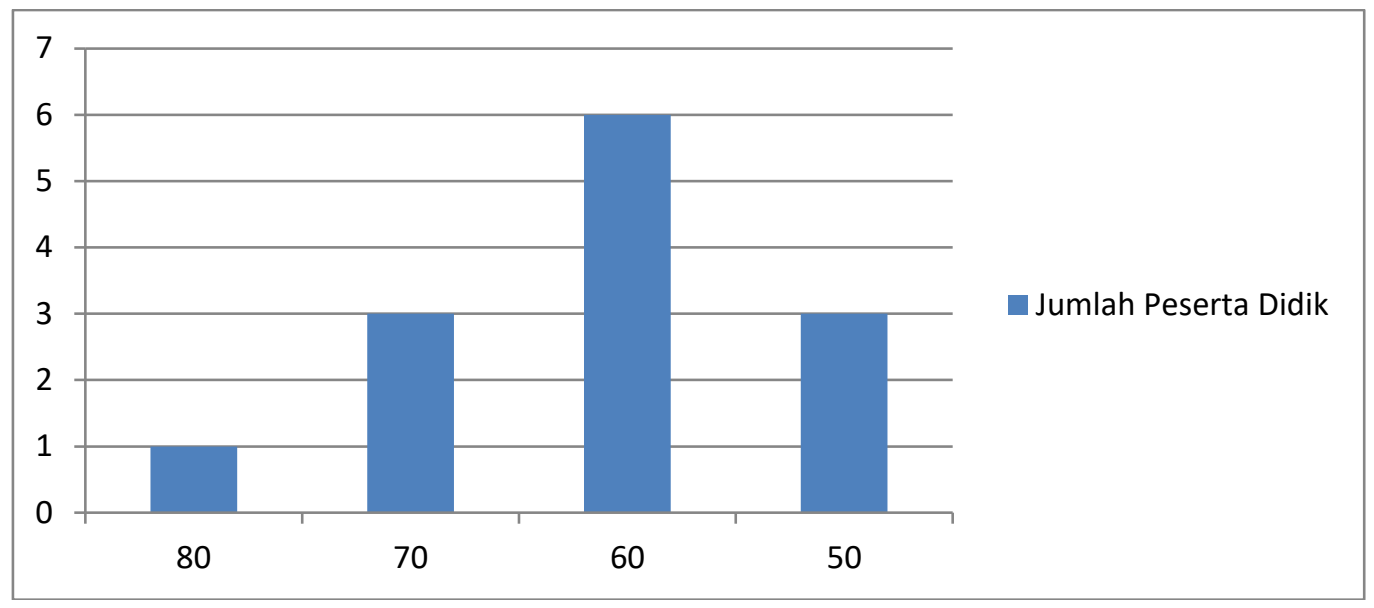

\section{Gambar 1. Diagram hasil belajar peserta didik prasiklus}

Kendala yang muncul pada pembelajaran prasiklus dapat dilihat oleh peneliti saat berlangsungnya proses pembelajaran dan hasil tes yang dilakukan setelah proses pembelajaran. Adapun kendala yang timbul pada pembelajaran prasiklus antara lain :

1) Keaktifan peserta didik dalam proses pembelajaran masih kurang.

2) Kemampuan peserta didik dalam menyelesaikan soal cerita tentang pengurangan dua bilangan cacah masih kurang.

Rancangan strategi penyelesaian masalah dan paparan langkah implementasi penyelesaian masalah dalam prasiklus :

1) Membuat lembar kerja yang dapat lebih mengaktifkan peserta didik pada pembelajaran siklus berikutnya.

2) Membuat soal cerita yang bervariasi yang mudah dipahami oleh peserta didik sehingga dapat meningkatkan kemampuan peserta didik dalam menyelesaikan soal cerita pengurangan dua bilangan cacah pada pembelajaran siklus berikutnya.

Setelah selesainya siklus I, peserta didik mengerjakan evaluasi dengan hasil sebagai berikut :

Dari 13 peserta didik yang mengikuti pembelajaran matematika dapat diketahui nilai tertinggi yang diraih peserta didik adalah 80 dan yang terendah adalah 50 , dengan rata-rata hasil evaluasi adalah 66 . Prosentase ketuntasan peserta didik yang diperoleh yaitu sebanyak $54 \%$ peserta didik tuntas dan $46 \%$ peserta didik belum tuntas. Adapun data lengkap perolehan nilai peserta didik prasiklus dapat dilihat pada tabel berikut :

Tabel 2. Rekapitulasi Hasil Belajar Peserta Didik Siklus I

\begin{tabular}{|c|c|c|c|}
\hline Nomor & Nilai & Frekuensi & Prosentase \\
\hline 1 & 80 & 2 & $15,3 \%$ \\
\hline 2 & 70 & 5 & $38,5 \%$ \\
\hline 3 & 60 & 5 & $38,5 \%$ \\
\hline 4 & 50 & 1 & $7,7 \%$ \\
\hline & Jumla & 13 & $100 \%$ \\
\hline
\end{tabular}


Dari data dalam tabel 2 di atas bila disajikan dalam bentuk diagram maka :



\section{Gambar 2. Diagram hasil belajar peserta didik siklus I}

Kendala yang muncul dalam pembelajaran siklus I dapat dilihat oleh peneliti saat berlangsungnya proses pembelajaran dan hasil evaluasi yang dilakukan setelah selesainya pembelajaran. Adapun kendala yang timbul pada pembelajaran siklus I antara lain :

1) Keaktifan peserta didik dalam proses pembelajaran cukup.

2) Kemampuan peserta didik dalam menyelesaikan soal cerita tentang pengurangan dua bilangan cacah cukup.

3) Keterampilan bertanya peserta didik cukup.

Rancangan strategi penyelesaian masalah dan paparan langkah implementasi penyelesaian masalah dalam siklus I :

1) Untuk mengaktifkan peserta didik pada pembelajaran siklus II dapat dilakukan dengan membuat lembar kerja yang dapat lebih mengaktifkan peserta didik.

2) Membuat soal cerita yang bervariasi yang mudah dipahami oleh peserta didik untuk meningkatkan kemampuan peserta didik dalam menyelesaikan soal cerita pengurangan dua bilangan cacah pada pembelajaran siklus II.

3) Membuat kegiatan yang meningkatkan keterampilan bertanya peserta didik pada siklus II.

Setelah selesainya siklus II, peserta didik mengerjakan evaluasi dengan hasil sebagai berikut :

Dari 13 peserta didik yang mengikuti pembelajaran matematika dapat diketahui nilai tertinggi yang diraih peserta didik adalah 100 dan yang terendah adalah 60, dengan rata-rata hasil evaluasi adalah 82. Prosentase ketuntasan peserta didik yang diperoleh yaitu sebanyak $92 \%$ peserta didik tuntas dan $8 \%$ peserta didik belum tuntas. Adapun data lengkap perolehan nilai peserta didik prasiklus dapat dilihat pada tabel berikut : 
Tabel 3. Rekapitulasi Hasil Belajar Peserta Didik Siklus II

\begin{tabular}{llll}
\hline Nomor & Nilai & Frekuensi & Prosentase \\
\hline 1 & 100 & 2 & $15,4 \%$ \\
2 & 90 & 4 & $30,7 \%$ \\
3 & 80 & 3 & $23,1 \%$ \\
4 & 70 & 3 & $23,1 \%$ \\
5 & 60 & 1 & $7,7 \%$ \\
\hline Jumlah & & 13 & $100 \%$ \\
\hline
\end{tabular}

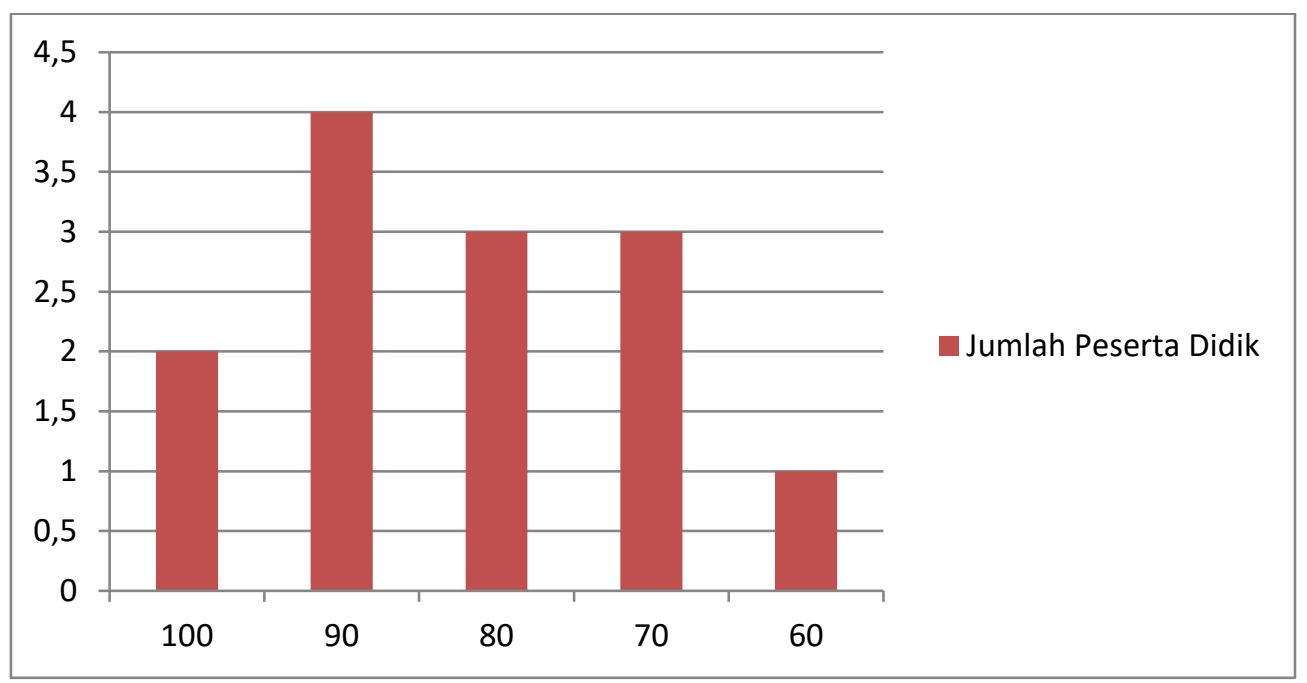

\section{Gambar 3. Diagram hasil belajar peserta didik siklus II}

Pembahasan dari prasiklus

a) Nilai rata-rata yang diperoleh sebesar 62 .

b) Peserta didik yang mendapatkan nilai 70 ke atas sebanyak 4 peserta didik.

c) Peserta didik yang mendapatkan nilai kurang dari 70 sebanyak 9 peserta didik.

d) Peserta didik yang telah dinyatakan memiliki ketuntasan belajar (dengan nilai 70 ke atas) sebanyak 4 peserta didik dari jumlah 13 peserta didik atau $31 \%$, sedangkan peserta didik yang belum tuntas sebanyak 9 peserta didik dari jumlah 13 peserta didik atau $69 \%$.

Pembahasan dari siklus I

a) Nilai rata-rata yang diperoleh sebesar 66 .

b) Peserta didik yang mendapatkan nilai 70 ke atas sebanyak 7 peserta didik.

c) Peserta didik yang mendapatkan nilai kurang dari 70 sebanyak 6 peserta didik.

d) Peserta didik yang telah dinyatakan memiliki ketuntasan belajar (dengan nilai 70 ke atas) sebanyak 7 peserta didik dari jumlah 13 peserta didik atau $54 \%$, sedangkan peserta didik yang belum tuntas sebanyak 6 peserta didik dari jumlah 13 peserta didik atau $46 \%$.

Pembahasan dari siklus II

a) Nilai rata-rata yang diperoleh sebesar 82 .

b) Peserta didik yang mendapatkan nilai 70 ke atas sebanyak 12 peserta didik.

c) Peserta didik yang mendapatkan nilai kurang dari 70 sebanyak 1 peserta didik.

Peserta didik yang telah dinyatakan memiliki ketuntasan belajar (dengan nilai 70 ke atas) sebanyak 12 peserta didik dari jumlah 13 peserta didik atau $92 \%$, 
sedangkan peserta didik yang belum tuntas sebanyak 1 peserta didik dari jumlah 13 peserta didik atau $8 \%$.

\section{SIMPULAN}

Berdasarkan hasil dan pembahasan dapat diketahui bahwa nilai rata-rata hasil belajar peserta didik pada prasiklus sebesar 62, pada siklus I sebesar 66, dan pada siklus II sebesar 82. Terjadi peningkatan nilai rata-rata hasil belajar peserta didik. Prosentase ketuntasan belajar peserta didik pada prasiklus sebesar $31 \%$, pada siklus I sebesar $54 \%$, dan pada siklus II sebesar $92 \%$ sehingga terdapat peningkatan prosentase ketuntasan belajar peserta didik.

Berdasarkan keterangan di atas, maka dapat disimpulkan bahwa penggunaan media powerpoint dapat meningkatkan hasil belajar matematika materi pengurangan dua bilangan cacah pada peserta didik kelas III SDN 03 Tegalsari Tahun Pelajaran 2020/2021.

Berdasarkan simpulan di atas, dapat diajukan beberapa saran :

1. Apabila peserta didik memiliki masalah mintalah bantuan kepada siapa saja yang dapat dipercaya.

2. Belajar jangan dirasakan sebagai beban tetapi suatu kebutuhan.

3. Dalam pembelajaran guru harus memilih media yang sesuai sehingga menarik minat peserta didik dalam belajar.

4. Guru hendaknya membina hubungan yang baik dengan peserta didik dan orang tua.

\section{DAFTAR PUSTAKA}

Daryanto. 2012. Media Pembelajaran. Bandung:Satu Nusa

Dimyati dan Mudjiono. (2009). Belajar dan Pembelajaran. Jakarta:Rineka Cipta.

Huda, F.A. (2018, Maret 21). Pengertian dan Langkah-Langkah Pembuatan Media Pembelajaran Powerpoint. Diakses dari http://fatkhan.web.id/pengertian-mediapembelajaran-powerpoint/

Irawan, D. (2013). Keefektifan Media Slide Presentasi terhadap Minat dan Hasil Belajar Siswa pada Pembelajaran Matematika Materi Bangun Datar di Kelas III Sekolah Dasar Negeri 06 Tegalsari Kabupaten Pemalang. Diakses dari http://lib.unnes.ac.id/17844/1/1401409308.pdf

Slameto. 2010. Belajar dan Faktor-faktor yang Mempengaruhinya. Jakarta: Rineka Cipta

Suprijono, A. 2009. Cooperative Learning:Teori \& Aplikasi PAIKEM. Yogyakarta: Pustaka Belajar

UU RI No. 20, 2003. Sistem Pendidikan Nasional. Jakarta: DPR RI.

Walgito, B. 2009. Pengantar Psikologi Umum. Yogyakarta: ANDI.

Wibawa, B. (2001). Media Pengajaran. Bandung:CV. Maulana. 